\title{
Induced Maturation of Prawn Penaeus indicus
}

\author{
W. D. Emmerson* \\ Fisheries Development Corporation of South Africa Ltd., P. O. Box 149, Gingindlovu 3800, Republic of South Africa
}

\begin{abstract}
Viable spawns have been obtained in the laboratory from untreated prawn Penaeus indicus and from others which had one eyestalk ablated. Fecundity was shown to be dependent on spawning technique, female size and whether the spawner was wild or domestic. Using low aeration during spawning, domestic unablated female fecundity was significantly lower than it was for wild females, due to a concomitantly smaller ovary volume. During late premoult, mature ovaries are resorbed to ovarian Stage 1-2 and after ecdysis they redevelop. $52.1 \%$ of spawnings occurred during early premoult, $44.4 \%$ during intermoult, $3.5 \%$ at premoult, while no spawns occurred during late premoult or early postmoult. Average egg numbers and hatch successes were higher for unablated females when compared with ablated females. Average spawns per moult cycle were 1.98 and 2.24 , respectively. It was conservatively estimated that wild females spawn at least $7-9$ times in a lifetime. There were twice the number of spawns with a black tank background as there were with a white one and the former yielded higher average egg numbers and hatch successes. General pigmentation, ovary, egg and nauplius colour was dependent on background colour. Moult-cycle duration was temperature dependent but generally shorter for ablated females. As female condition decreased, moult-cycle duration decreased accordingly for any given temperature. Spawning activity declined when the condition factor was less than 0.8. Both ablated and unablated spawning females $>39 \mathrm{~g}$ tended to decrease in mass and condition while females $<39 \mathrm{~g}$ continued to grow. Nutrition is probably the main contributory factor to this anomalous growth. Large females possibly have nutritional requirements different from females of less than $39 \mathrm{~g}$. A viable $F_{2}$ generation of $P$. indicus has been reared.
\end{abstract}

\section{INTRODUCTION}

Both the cost and unreliability of obtaining wild gravid stock make controlled maturation vital to commercial penaeoid farming. Once the controlling factors are fully understood, females can be matured whenever larvae are required. Although these factors have yet to be completely identified, light intensity and photoperiod appear to be important parameters (Aiken, 1969; Weinberg, 1976). Penaeoidea have previously been matured domestically by ablating eyestalks, reducing light intensity, manipulating photoperiod, or by a combination of these factors (Arnstein and Beard, 1975; Laubier-Bonichon and Laubier, 1976). With these latter parameters as guidelines, a programme was launched to mature the penaeoid Penaeus indicus. It was found that when light intensity was reduced, both ablated and unablated adult females became gravid and spawned, yielding viable larvae. This facilitated a study to compare wild and domestic spawning performances; to relate spawning to the moult cycle; to estimate individual spawning potential; and to assess the problem of relative condition changes in domestically held females. For a recent review on prawn cultivation consult 'Marine Ecology', Volume III: Kinne, 1977, pp. 840-858.

\section{MATERIAL AND METHODS}

Four cylindrical, thermostatically controlled $8000 \mathrm{l}$ glass-fibre tanks, $1.35 \mathrm{~m}$ deep, were used as outdoor maturation vessels. Lids reduced light intensity to approximately $70 \mu \mathrm{W} \mathrm{cm} \mathrm{cm}^{-2}$. Gravid Penaeus indicus females usually exceeding $27 \mathrm{~g}$ in mass and mature males larger than $17 \mathrm{~g}$, were trawled from the Tugela Bank $\left(29^{\circ} 10^{\prime} \mathrm{S}\right)$ and introduced into the tanks in the ratio of 12 females to 8 males (3:2). Wild freshlytrawled females usually spawned during the first or second night in captivity. Domestic females (prawns kept under artificial conditions) were usually recruited from spent wild spawners. Initially, half the females were ablated to stimulate ovarian development (Panouse, 1943; Brown and Jones, 1947; Adiyodi and Adiyodi, 1970; Caillouet, 1973; Ryckaert et al., 1974; Alikunhi et al., 1975; Wear and Santiago, 1976; Santiago, 1977). Each female was code-marked to facilitate daily ovary staging and to establish when ecdysis and impregnations occurred. Four arbitrary stages of ovary development were used instead of five (King, 1948; Subrahmanyam, 1965; Joubert and Davies, 1966;

\footnotetext{
- Present address: University of Port Elizabeth, P. O. Box 1600, Port Elizabeth 6000, Republic of South Africa.
} 
Rao, 1967), as visibly there was little difference between a spent (Stage 5) and a Stage 1-2 ovary. The stages of ovary development were arbitrary and based on the ratio between maximum ovary width (OW) to greatest width of the first abdominal segment (SW). The OW : SW ratios were as follows: ovarian Stage 1, 0.1 ; Stage 2, 0.2; Stage 3, 0.35 and Stage 4, 0.4. Females were moult staged by microscopic uropod inspection (Cognie, 1970; Aiken, 1973; Read, 1977). The following moult stages were recognised: $A$, early postmoult; $B_{1}$ postmoult; $C$, intermoult; $D_{0-1}$, early premoult; $D_{2}$, premoult; $D_{3}$, late premoult; and $E$, ecdysis. When females reached ovarian Stage 4, they were removed and allowed to spawn individually in $70 \mathrm{l}$ bins held at $26^{\circ} \mathrm{C}$. Initially, vigorous aeration was used in the spawning bins (Beard et al, 1977) but this was later reduced to 4 bubbles $\mathrm{s}^{-1}$. Egg and nauplii numbers were estimated by counting four $250 \mathrm{ml}$ aliquot subsamples. A relative condition factor $K n$, with the population average taken as one was established for $P$. indicus after Le Cren (1951) using the population length-freshmass relationship $M=0.00079 L^{2.9813}$ (Read and Caulton, in press) where $M=$ mass in grams and $L=$ carapace length in $\mathrm{mm}$.

$$
K n=\frac{1266 . M}{L^{2.9813}}
$$

A prawn in good condition would thereby have a factor $>1.0$ and a prawn in poor condition, $<1.0$. Females were weighed prior to spawning after blotting dry. Carapace lengths (CL) were simultaneously taken averaging left and right measurements from the post orbital notch to the posterior carapace margin. Total length (TL) measurements were taken from rostrum tip to telson tip. Prawns were fed twice daily on a formulated dry pellet (fishmeal, $40 \%$; prawnmeal, $30 \%$; flour, $15 \%$; cholesterol, $5 \%$; mineral mix, $4 \%$; vitamin mix, $2 \%$; choline chloride, $2 \%$; and anchovy oil, $2 \%$ at $2.5 \%$ and fresh frozen prawn at approximately $3.5 \%$ of total fresh mass. Water exchange was $30 \%$ per two days while the physico-chemical parameters, namely temperature, $\mathrm{pH}$, salinity, oxygen, total ammonia (Solorzano, 1969) and nitrite (Bendschneider and Robinson, 1952) were monitored daily. Tank temperatures between $20.5^{\circ}$ and $25.5^{\circ} \mathrm{C}$ corresponded to the annual range for Natal inshore waters (Heydorn et al., 1978). To test the effect of background colour on ovary pigmentation, one tank was painted black inside and another painted white while only unablated females were used.

\section{RESULTS}

The physico-chemical parameters for the experimental period are listed in Table 1. Viable spawns were obtained throughout the year for unablated fe-

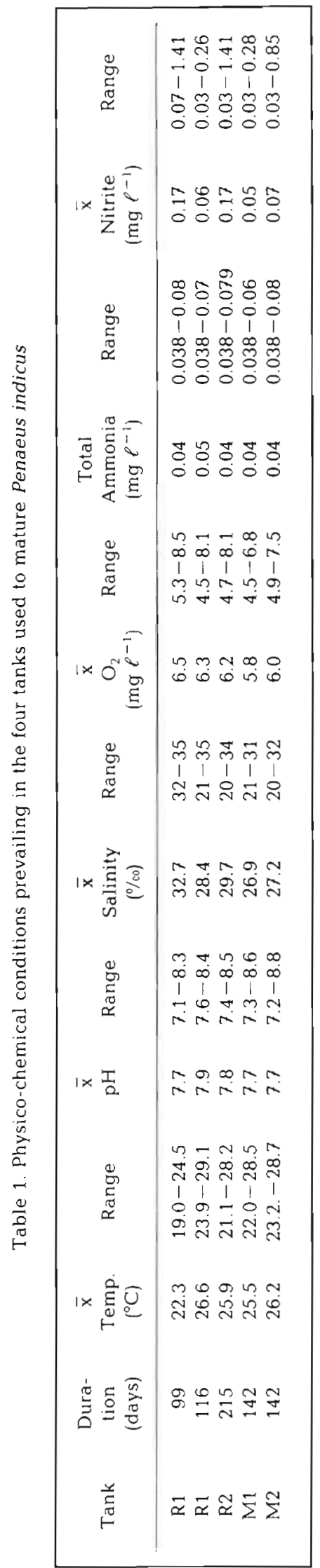


males and for 7 months with ablated females after which time ablation was discontinued. Ablated females were the first to spawn accounting for $76.5 \%$ of the first month's spawns $(n=17)$. Impregnation rates were good $(95.4 \%)$ and spermatophores were usually resorbed into the thelycum within $6 \mathrm{~h}$ after impregnation.

\section{Fecundity}

Fecundity, defined as the number of ova extruded on complete evacuation of the ovaries, but excluding aborts and poor spawns ( $<10000$ ova), varied with

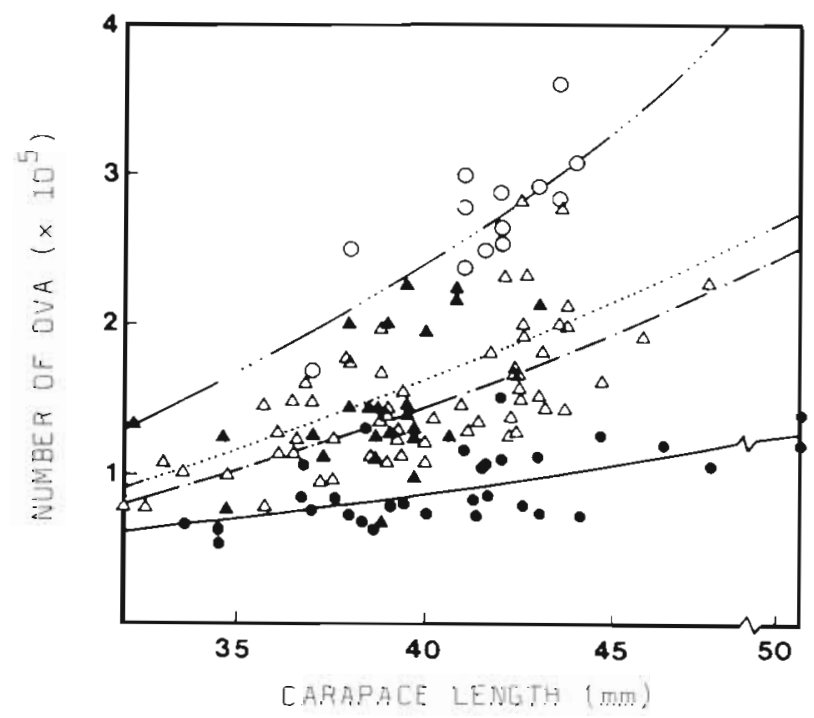

Fig. 1. Penaeus indicus. Relationship between fecundity (number of ova) and size (carapace length). Circles: wild females; triangles: domestic females under low aeration. vigorous aeration; $\bigcirc$ low aeration; $\Delta$ unablated; $\boldsymbol{\Delta}$ ablated spawning technique, female size and whether the spawner was wild or domestic (Fig. 1). These regressions, tested by covariance analysis (Snedecor and Cochran, 1967), are shown in Table 2.

Ablation (1 vs 2, Table 2), was found to have no differential effect on fecundity with female size. Ablation may, however, have had an effect on fecundity (marginally not significant) to yield more ova per unit size female. Using low aeration during spawning there was no significant difference in slope $(\beta)$ between wild and unablated domestic females (2 vs 3, Table 2). There was nevertheless a highly significant difference in elevation $(\propto)$ which indicated that wild females were more fecund per unit size animal. When comparing vigorous and low aeration for wild spawners ( 3 vs 4, Table 2) slopes were not significantly different. Elevations were highly significantly different demonstrating that the low aeration increased fecundity greatly per unit size female.

\section{Spawning in Relation in the Moult Cycle}

During late premoult (Stage $D_{2}$ to $D_{3}$ ) the ovaries resorbed to ovarian Stage 1 (Fig. 2) in small females or Stage 2 in larger females (>33 g). Alternatively, premoult females reverted to ovarian Stage $1-2$ via a spawn. After ecdysis (E) the ovaries redeveloped during postmoult (B) and intermoult (C) through to early premoult $\left(D_{0-1}\right)$. Females evacuated (spawns including aborts) up to three times before moulting again. Other than one ablated animal which evacuated four consecutive times during one moult cycle on two separate occasions, the pattern was similar for both ablated and unablated females (Fig. 2 and Table 3).

Table 2. Penaeus indicus. Comparison of fecundity/female size regressions for four spawner types using covariance analysis after Snedecor and Cochran (1967). $\mathrm{S}^{\cdots}$ : Highly significant; NS ${ }^{+}$: marginally not significant; NS: not significant; E: ova number; L: carapace length in $\mathrm{mm}$

\begin{tabular}{|c|c|c|c|c|c|c|c|c|c|c|c|}
\hline No. & Spawner type & $E=a L^{b}$ & $n$ & $r$ & $\begin{array}{l}\text { Compa- } \\
\text { rison }\end{array}$ & $F$ & $\begin{array}{l}\text { Slopes } \\
\text { d.f. }\end{array}$ & $\begin{array}{c}(\beta) \\
p\end{array}$ & $F$ & $\begin{array}{c}\text { Eleva- } \\
\text { tions } \\
\text { d. f. }\end{array}$ & $\begin{array}{l}(\propto) \\
p\end{array}$ \\
\hline 1 & $\begin{array}{l}\text { Domestic ablated } \\
\text { low aeration }\end{array}$ & $E=20.060 \mathrm{~L}^{2.4362}$ & 24 & 0.528 & $1 / 2$ & 0.008 & $1: 85$ & $\begin{array}{c}\text { NS } \\
0.929\end{array}$ & 3.4 & $1: 86$ & $\begin{array}{l}\mathrm{NS}^{+} \\
0.06\end{array}$ \\
\hline 2 & $\begin{array}{l}\text { Domestic unablated } \\
\text { low aeration }\end{array}$ & $E=16.088 \mathrm{~L}^{2.4696}$ & 65 & 0.735 & $2 / 3$ & 0.065 & $1: 74$ & $\begin{array}{l}\text { NS } \\
0.799\end{array}$ & 78.53 & $1: 75$ & $\begin{array}{l}\mathrm{S} \cdots \\
0.001\end{array}$ \\
\hline 3 & $\begin{array}{l}\text { Wild } \\
\text { low aeration }\end{array}$ & $E=9.262 \mathrm{~L}^{2.7599}$ & 13 & 0.804 & $3 / 4$ & 0.931 & $1: 40$ & $\begin{array}{l}\text { NS } \\
0.34\end{array}$ & 287,24 & $1: 41$ & $\stackrel{S}{S} \cdot$ \\
\hline 4 & $\begin{array}{l}\text { Wild } \\
\text { vigorous aeration }\end{array}$ & $E=183.714 \mathrm{~L}^{1.6719}$ & 31 & 0.633 & & & & & & & \\
\hline
\end{tabular}


(1)

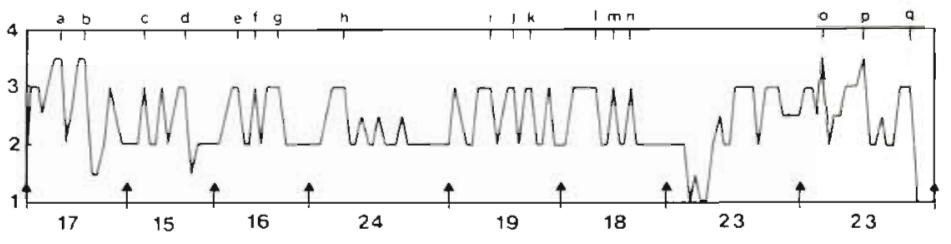

(2)

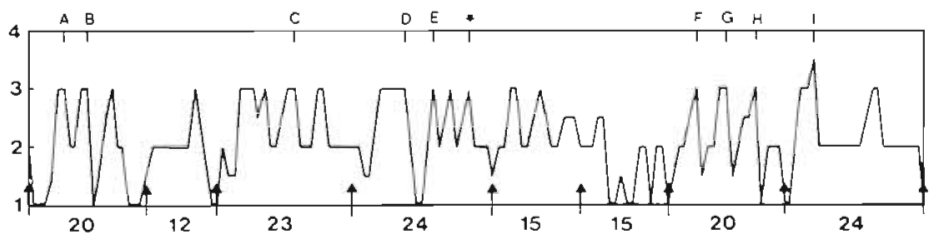

(3)

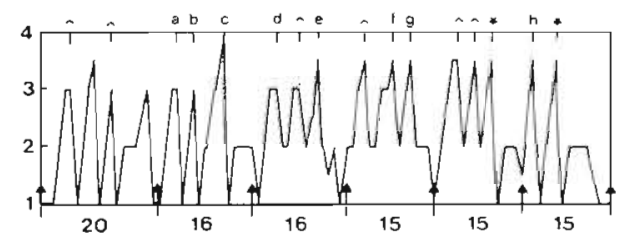

(4)

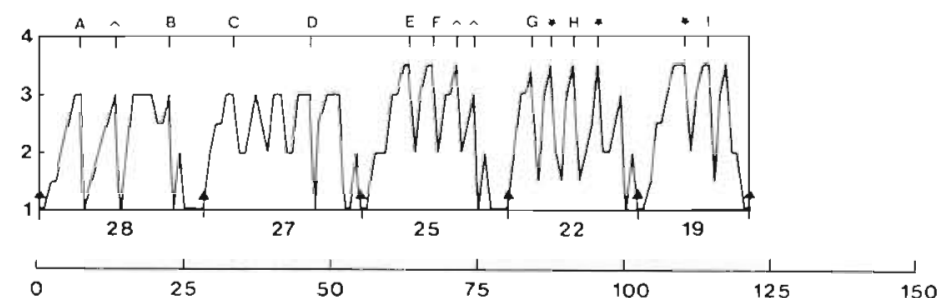

Fig. 2. Penaeus indicus. Progressive ovary development for examples of two unablated (1 and 2) and two ablated (3 and 4) females. Vertical arrows: ecdysis; numbers between arrows: moult-cycle durations. Spawns are represented alphabetically (a-q, A-I) with vertical stipled lines, details of which are given in Table 3. " tank spawns; aborts

Table 3. Penaeus indicus. Progressive spawns of two unablated and two ablated females as represented in Figure $2 . \% \mathrm{H}$ : percentage hatch

\begin{tabular}{|c|c|c|c|c|c|c|c|c|c|c|c|c|c|c|c|}
\hline & \multicolumn{7}{|c|}{ Unblated } & \multicolumn{8}{|c|}{ Ablated } \\
\hline & \multicolumn{3}{|c|}{1} & & \multicolumn{3}{|c|}{2} & & \multicolumn{3}{|c|}{3} & & \multicolumn{3}{|c|}{4} \\
\hline & Ova & $n$ & $\% \mathrm{H}$ & & Ova & $n$ & $\% \mathrm{H}$ & & Ova & $n$ & $\% \mathrm{H}$ & & Ova & $n$ & $\% \mathrm{H}$ \\
\hline $\mathrm{a}$ & 165 & 200 & 95.3 & A & 228 & 480 & 95.8 & a & 28 & 840 & 6.8 & A & 17 & 010 & 32.1 \\
\hline $\mathrm{b}$ & 201 & 320 & 96.5 & B & 112 & 560 & 96.5 & $\mathrm{~b}$ & 140 & 000 & 55.2 & B & 53 & 480 & 0 \\
\hline c & 157 & 080 & 75.4 & C & 132 & 440 & 0 & c & 87 & 080 & 23.8 & C & 147 & 840 & 93.2 \\
\hline $\mathrm{d}$ & 171 & 640 & 66.2 & $D$ & 127 & 400 & 6.6 & d & 145 & 880 & 74.5 & $D$ & 228 & 480 & 0 \\
\hline $\mathrm{e}$ & 115 & 920 & 79.4 & $\mathrm{E}$ & 102 & 200 & 18.3 & $\mathrm{e}$ & 15 & 680 & 20.5 & $E$ & 38 & 080 & 18.4 \\
\hline $\mathrm{f}$ & 128 & 520 & 88.8 & $\mathrm{~F}$ & 142 & 240 & 87.8 & $E$ & 31 & 360 & 16.1 & $F$ & 76 & 720 & 35.4 \\
\hline$g$ & 112 & 280 & 97.0 & $\mathrm{G}$ & 165 & 760 & 85.8 & $g$ & 11 & 480 & 75.6 & $G$ & 48 & 720 & 68.4 \\
\hline $\mathrm{h}$ & 123 & 480 & 83.2 & $\mathrm{H}$ & 95 & 760 & 86.8 & $\mathrm{~h}$ & 96 & 040 & 61.5 & $\mathrm{H}$ & 131 & 320 & 99.4 \\
\hline $\mathrm{i}$ & 126 & 280 & 0 & I & 115 & 360 & 77.0 & i & & & & I & 17 & 640 & 69.4 \\
\hline j & 105 & 000 & 36.6 & & & & & & & & & & & & \\
\hline $\mathrm{k}$ & 150 & 080 & 85.4 & & & & & & & & & & & & \\
\hline 1 & 138 & 880 & 14.6 & & & & & & & & & & & & \\
\hline $\mathrm{m}$ & 283 & 640 & 98.9 & & & & & & & & & & & & \\
\hline $\mathrm{n}$ & 182 & 560 & 87.0 & & & & & & & & & & & & \\
\hline 0 & 94 & 920 & 14.6 & & & & & & & & & & & & \\
\hline $\mathrm{p}$ & 102 & 760 & 22.3 & & & & & & & & & & & & \\
\hline$q$ & 127 & 680 & 61.0 & & & & & & & & & & & & \\
\hline
\end{tabular}


significant so that a black background could possibly improve fecundity. General prawn pigmentation, ovaries, eggs and nauplii took on the background colour. White tank females developed very pale green to cream coloured ovaries, whereas black-tank females had dark olive green ovaries, similar to the colour of wild female ovaries.

\section{Condition and Moult-Cycle Duration}

No clear relationship was found between spawning female size and moult-cycle duration. Moult-cycle duration was, however, correlated with mean temperature per moult cycle for both ablated and unablated

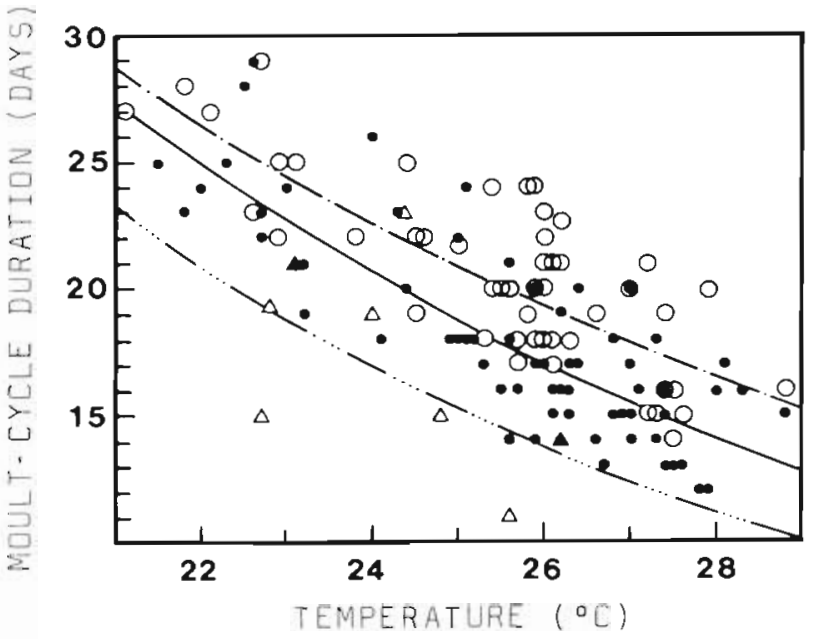

Fig. 3. Penaeus indicus. Relationship between moult-cycle duration and temperature for unablated females. $O k n>0.94$; $r=0.76 ; n=57 . \bullet 0.8<k n<0.94 ; r=0.801 ; n=68 . \Delta k n<$ $0.8 ; r=0.557 ; n=8$

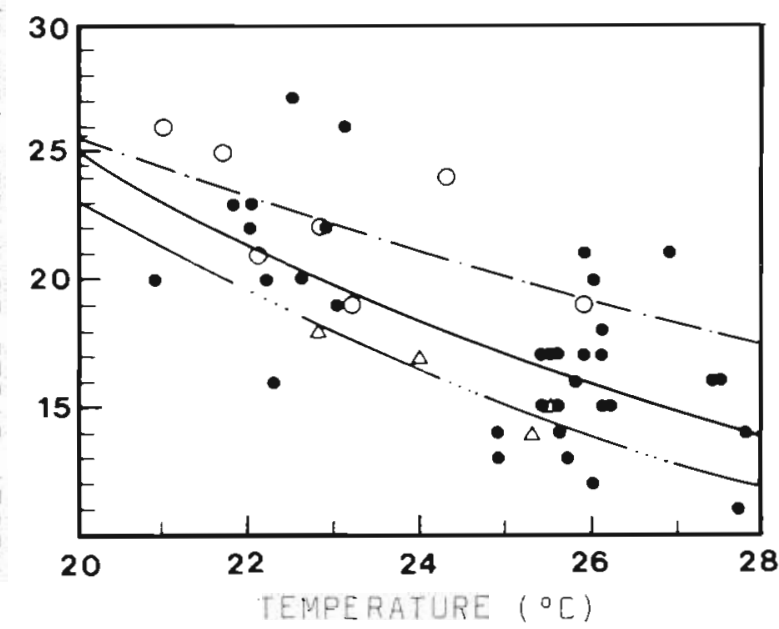

Fig. 4. Penaeus indicus. Relationship between moult-cycle duration and temperature for ablated females. $O k n>0.94$; $r=0.63 ; n=7 . \bullet 0.8<k n<0.94 ; r=0.668 ; n=39 . \Delta k n$ $<0.8 ; r=0.934 ; n=4$

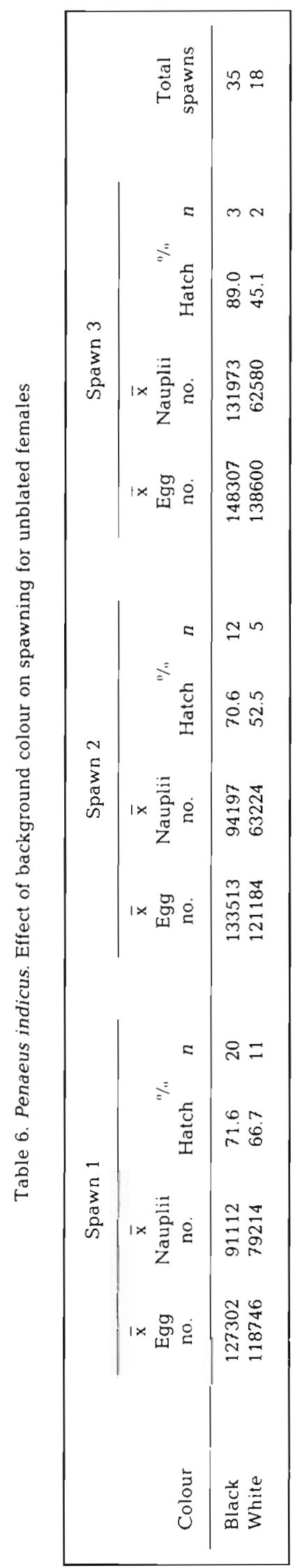


females for three condition groups. These groups were taken as above 0.94 , between 0.8 and 0.94 and below 0.8 (Figs 3 and 4 ). The duration of the moult cycle was temperature dependent, the lower the temperature the longer the duration. Especially at the lower temperatures, ablated females (Fig. 4) had shorter moult cycles than their unablated counterparts (Fig. 3). As temperature increased, moult-cycle duration decreased until there was approximately the same duration for ablated and unablated females. This probably occurred because moulting is a complex physiological process and the cycle must take a minimum time to complete. As ablated and unablated female condition decreased, moult-cycle duration decreased accordingly at any given temperature. Below a condition factor of 0.8 spawning activity declined, the female usually failed to harden properly after ecdysis and died. Good condition must therefore be maintained for females to withstand moulting stress and continue to spawn. All domestic spawners in good condition were generally found to be below $39.0 \mathrm{~g}$. Change in mass, $\Delta \mathrm{g}$ month $^{-1}$ was plotted against initial mass (Fig. 5). During the first month in the tanks growth was depressed as the prawns acclimated to their new conditions. Thus only subsequent data was used. Both unablated and ablated prawns below $39 \mathrm{~g}$ tended to increase in mass while above $39 \mathrm{~g}$ they lost mass. This was observed independently in four separate maturation tanks over a 12-month period.

\section{DISCUSSION AND CONCLUSIONS}

The ammonia and nitrite levels in the maturation tanks were well within the maximum acceptable level for prawns given by Wickins (1976). Penaeus indicus in their natural environment have been shown to spawn throughout the year with greater spawning frequencies in autumn and early summer (Panikkar and Menon, 1956; George, 1962; Crosnier, 1965; Subrahm- anyam, 1965; Rao, 1967; George et al., 1967; Le Reste and Marcille, 1976). Although seasonal trends were not duplicated domestically, viable spawns were nevertheless obtained throughout the year for unablated females.

\section{Spawning and Fecundity}

The best fecundity was obtained from recently captured wild females using low aeration (Table 2 ). The exponent $(\beta)$ describing fecundity for this group (2.7599, Table 2$)$ is close to the theoretical value of 3 and since the number of ova produced is a function of ovary volume and thus the cube of the length (MacGregor, 1957; Martosubroto, 1974), this would be expected to represent near maximum fecundity. Rao (1968) obtained a fecundity for Penaeus indicus which was proportional to the 6th power of the total length (cf. P. semisulcatus; Badawi, 1975). Martosubroto (1974) obtained an exponent of 3.36 for $P$. duorarum but noted Rao's value to be high. Spawning with low aeration vastly improved spawn quality, fecundity and hatch success. Vigorous aeration probably had a disturbing effect on incipient spawners. Cummings (1960, 1961) and Martosubroto (1974) have suggested that the ripening of the ova immediately prior to evacuation is very short, perhaps only hours long. Overnight holding conditions would thus be critically important for the complete and successful evacuation of properly formed ova.

Ablation may have a marginally positive effect on the fecundity of domestic stock, but average egg numbers and hatch successes were lower than they were for unablated spawners. This was due to a greater number of poor spawns and aborts compared with unablated females. These factors in turn were probably due to the rapidity of ovary development in ablated females which yielded "rushed" spawns where the eggs were not properly matured.

The difference in fecundity between domestically

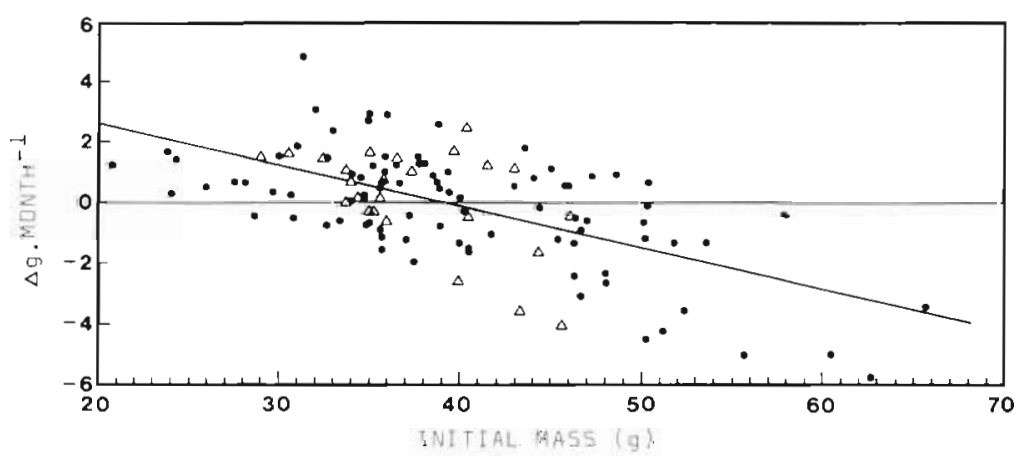

Fig. 5. Penaeus indicus. Relationship between initial mass $(\mathrm{g})$ and change in mass $\left(\triangle \mathrm{g}\right.$ month $\left.^{-1}\right)$ for combined unablated $(\bullet)$ and ablated $(\triangle)$ domestic females 
held unablated females and wild females was probably due to two main reasons. Firstly, domestic females spawned at a narrower ovary width than wild spawners and secondly, they often had breaks in the ovary due to collisions with the tank walls. Both these factors decreased ovary volume and resulted in a lower fecundity per unit size female.

\section{Ovarian Cycle Versus Moult Cycle}

The ovarian cycle has been shown to be closely linked with the moult cycle (Table 4). The Aquacop Team (1975) noted that they had never seen a penaeoid moulting with developed ovaries except for a bilaterally ablated Penaeus aztecus. Martosubroto (1974) has shown histological evidence of resorbed ova in $P$. duorarum. Ovarian development may inhibit moulting in certain species of crab (Weitzman, 1964; Cheung, 1966, 1969; Adiyodi, 1968). In lobsters and crayfish, however, the moult cycle appears to be of overriding importance with ecdysis occuring during various stages of ovary development (Berry, 1971; Rice and Armitage, 1974; Aiken and Waddy, 1976). The Penaeoidea thus appear to be similar to the latter in that moulting is of prime importance, but differ in that there is never ovarian development during ecdysis. Read and Caulton (in press) have shown that ovary maturation is associated with water loss in wild $P$. indicus. Ecdysis has long been associated with water uptake in Crustacea (Passano, 1960) and since those two functions are antagonistic, it may be possible that water uptake prior to ecdysis inhibits ovarian development causing resorption of the ovary.

\section{Hatch Success}

A trend shown by ablated and unablated females was a decrease in hatch success (number of nauplii) with successive spawns per moult cycle. One unablated female (Fig. 2 and Table 3), however produced 458920 nauplii from three spawns during one moult cycle. The normal impregnation of two spermatophores thus proved enough to fertilise three successive spawns. The decrease in hatch success with successive spawns was therefore not believed to be a function of sperm depletion, but rather a reflection of decreasing spawn quality.

\section{Spawn Frequency}

Predictions of spawning frequency by Penaeus indicus have been made by Subrahmanyam (1965) and Rao
(1967). Subrahmanyam stated that a female was capable of releasing several broods in a season, while Rao estimated a total of five spawnings during the life of an individual (cf. $P$. semisulcatus, Badawi, 1975). Hudinaga (1942) and Lindner and Anderson (1956) observed prawns spawning more than once in a season. Cummings $(1960,1961)$ and Eldred et al, 1961) suggested multiple spawnings for $P$. duorarum based on modal shifts. Burukovski (1970) suggested an interval of 2-3 months between spawns for P. duorarum. For domestic stocks, Laubier-Bonichon and Laubier (1976) and the Aquacop Team (1975) have shown multiple spawnings for $P$. japonicus, while Primavera and Borlongan (1977) have demonstrated rematuration in Penaeus monodon. Although it would appear that overstimulation of spawning can occur in domestic $P$. indicus, even for unablated females (one spawned 19 times in 7 months), it appears likely that wild females are capable of spawning more than five times during their lifetime when the following projections are considered.

Penaeus indicus females commence breeding at approximately $27 \mathrm{~mm}$ CL (137 $\mathrm{mm}$ TL) in Madagascan waters (Le Reste and Marcille, 1976) and $33 \mathrm{~mm} \mathrm{CL}$ (158 mm TL) in South African waters (Read and Champion, personal communication). By tagging wild $P$. indicus, Le Reste and Marcille established a growthcurve relationship between total length and time using the Fabens (1965) modified Von Bertalannfy (1958) equation. Breeding commencement corresponded to 5-6.5 month old females. They estimated that the female asymptotic size where growth is nil (approximately $178 \mathrm{~mm}$ TL) is attained after approximately 14 months yielding a breeding period of between 7.5 and 9 months. Assuming an average of one spawn per moult cycle, 7-9 spawns per life time is estimated. This also assumes that the female ceases to breed and dies on attaining terminal growth. In South African waters the asymptotic size $(55 \mathrm{~mm} \mathrm{CL}, 220 \mathrm{~mm}$ TL; Champion personal communication) is larger than that for the Madagascan population which on extrapolation would correspond to a female of between 25 and 30 months old, still in breeding condition (16-22 spawns per life time). This figure represents the possible number of spawns however, and not the population mean. Monthly trawls on the Tugela Bank for a full yearly cycle (Champion, personal communication) and periodic trawls for mature prawns have both shown the modal size of $P$. indicus to be $40 \mathrm{~mm}$ CL or $178 \mathrm{~mm}$ TL ( $n=2849$ and 1179, respectively), the same as the Madagascan asymptote. This corresponds to a modal female population age of approximately 14 months which have been actively breeding for 7.5-9 months, i.e. the majority of the female population at any time have spawned $7-9$ times. 


\section{Background Colour}

Black tanks appeared to be the more suitable for maturation probably as they absorbed more light, enabling the females to mature more fully. The ovaries of domestically matured prawns change colour with background colour and therefore cannot be staged using colour as a criterion, as in wild females (King, 1948; Cummings, 1961; Subrahmanyam, 1965; Joubert and Davies, 1966; Rao, 1967; Brown and Patlan, 1974).

\section{Moult Frequency}

The best line of fit describing the relationship between moult-cycle duration and temperature $\left(21^{\circ}-29^{\circ} \mathrm{C}\right)$ was exponential. Richard (1978) found an identical relationship for the shrimp Palaemon serratus. Aiken and Waddy (1976) however, report a linear relationship between temperature and moult frequency for Homarus americanus from $5^{\circ}-20^{\circ} \mathrm{C}$.

\section{Condition and Growth}

Although the relative condition ( $\mathrm{Kn}$ ) of the population is one, spawning females were consistently below this value. The average $K n$ for domestic spawners was only 0.903 and for wild spawners, 0.933. This anomaly is possibly associated with water loss and a fresh mass decrease with progressive ovary development (Read and Caulton, in press). Thomas (1975) plotted changes in relative condition for wild Penaeus semisulcatus and suggested that peaks represented cyclic gonad development and spawning. Balbontin et al. (1973) and Blaxter $(1971,1976)$ have shown that domestically reared herring have higher condition factors than wild fish due to abnormal allometric growth. Prawns used were initially wild as adults and lost mass and condition with domestication. Thus poor growth was not due to allometric abnormalities, but due to a genuine loss in condition. This was largely confined to females of $>39 \mathrm{~g}$. Improved nutrition may improve growth in large females. Somatic and reproductive growth have been shown to be antagonistic in many species of berry-carrying Crustacea including decapods (Demeusy, 1965; Bliss, 1966; Adiyodi and Adiyodi, 1970; Aiken and Waddy, 1976). For wild P. indicus and probably other species of the Penaeoidea, which do not carry berry, these two integrated processes may proceed synergistically but in captive females the balancing of these processes could depend on controlling factors such as nutrition, temperature, light quality and intensity, photoperiod and container size.

Larvae produced from domestic unablated females have been reared to maturity. The $F_{1}$, in turn, has been induced to spawn yielding viable larvae $\left(\mathrm{F}_{2}\right.$ generation). The development from egg to maturation and spawning, i.e one generation, took $255 \mathrm{~d}$. A level of independence from wild stocks has thus been achieved making a commercial undertaking for culturing Penaeus indicus more realistic.

Acknowledgements. I wish to express my appreciation to Dr. M. S. Caulton for his counsel and critical reading of the manuscript. D. Hayes and M. Ngonyama rendered technical assistance and D. T. Cooke effected the line drawings. I would also like to thank G. H. L. Read and H. F. B. Champion for making available unpublished data. Research was funded by the Fisheries Development Corporation of South Africa Limited.

\section{LITERATURE CITED}

Adiyodi, R. G. (1968). On reproduction and moulting in the crab Paratelphusa hydrodromous. Physiol. Zoöl. 41: 204-209

Adiyodi, K. G., Adiyodi, R. G. (1970). Endocrine control of reproduction in decapod crustacea. Biol. Rev, 45: 121-165

Aiken, D. E. (1969). Photoperiod, endocrinology and the crustacean moult cycle. Science, N. Y 164: 149-155

Aiken, D. E. (1973). Proecdysis, setal development and moult prediction in the American lobster (Homarus americanus). J. Fish. Res. Bd Can. 30: 1337-1344

Aiken, D. E., Waddy, S. L. (1976). Controlling growth and reproduction in the American lobster. In: Avault, J. W. (ed.) Proceedings of the Seventh Annual Meeting World Mariculture Society. Louisiana State University, Baton Rouge, pp. 415-430

Alikunhi, K. H., Poernomo, A., Adisukresno, S., Budiono, M., Busman, A. (1975). Preliminary observation on induction of maturity and spawning in Penaeus monodon Fab. and Penaeus merguiensis de Man by eyestalk extirpation. Bull. Shrimp Culture Res. Centre Japara 1: 1-11

Aquacop (1975). Maturation and spawning in captivity of penaeid shrimp: Penaeus merguiensis de Man, Penaeus japonicus Bate, Penaeus aztecus Ives, Metapenaeus ensis de Haan, and Penaeus semisulcatus de Haan. In: Avault, J. W., Miller, R. (eds) Proceedings of the Sixth Annual Meeting World Mariculture Society. Louisiana State University, Baton Rouge, pp. 123-129

Arnstein, D. R., Beard, J W. (1975). Induced maturation of the prawn Penaeus orientalis Kishinouye in the laboratory by means of eyestalk removal. Aquaculture 5: 411-412

Badawi, H. K. (1975). On maturation and spawning in some penaeid prawns of the Arabian Gulf. Mar. Biol. 32: 1-6

Balbontin, F., de Silva, S. S., Ehrlich, K. F. (1973). A comparative study of anatomical and chemical characteristics of reared and wild herring. Aquaculture 2: 217-240

Beard, T. W. Wickins, J. F., Arnstein, D. R. (1977). The breeding and growth of Penaeus merguiensis De Man in laboratory recirculation systems. Aquaculture 10: 275-289

Bendschneider, K., Robinson, R. J. (1952). A new spectrophotometric method for the determination of nitrite in seawater, J. Mar. Res. 11, 87--96

Berry, P. F. (1971). The biology of the spiny lobster Panulirus homarus (Linnaeus) off the East Coast of Southern Africa. Invest. Rep. oceanogr. Res. Inst. 28: 1-75 
Blaxter, J. H. S. (1971). Feeding and condition of Clyde herring larvae. Rapp. R.-v. Reun. Cons. int. Explor. Mer. 160: $128-136$

Blaxter, J. H. S. (1976). Reared and wild fish - how do they compare? In: Persoone, G, Jaspers, E. (eds) Proceedings of the 10th European Symposium of Marine Biology, Vol. 1 Universa Press, Wetheren, Belgium, pp. 11-26

Bliss, D. E. (1966). Relation between reproduction and growth in decapod crustaceans. Am. Zool. 6: 231-233

Brown, F. A. Jr., Jones, G. M. (1947), Hormonal inhibition of ovarian growth in the crayfish, Cambarus. Anat. Rec. 99 657

Brown, A. Jr., Patlan, D. (1974), Colour changes in the ovaries of penaeid shrimp as a determinant of their maturity. Mar. Fish. Rev. 36: 23-26

Burukovski, R. N. (1970). Certain aspects of oogenesis in the pink shrimp. Archs. Anat. Histol. Embryol. 58: 56-66

Caillouet, C. W. Jr. (1973). Ovarian maturation induced by eyestalk ablation in pink shrimp, Penaeus duorarum Burkenroad. In: Avault, J. W. (ed.) Proceedings of the Third Annual Meeting World Mariculture Society. Louisiana State University, Baton Rouge, pp. 205-225

Caubere, J.-L., Lafon, R., René, F., Sales, C. (1976). Maturation et ponte chez Penaeus japonicus en captivité, éssai de contrôle de cette reproduction à Maguelone sur les côtes Francaises. FAO Technical Conference on Aquaculture, Kyoto, Japan, Paper no. E. 49: 1-17

Cheung, T. S. (1969). The environmental and hormonal control of growth and reproduction in the adult female stone crab, Menippe mercenaria (Soy). Biol. Bull. mar. biol. Lab., Woods Hole 136: 327-346

Cognie, D. (1970). Contribution à l'étude de la biologie de Penaeus kerathurus (Forskål, 1775) en fonction du cycle d'intermue. Thèse 3ème Cycle, Universite d'Aix-Marseille II.

Crosnier, A. (1965). Les crevettes penaeides du plateau continental Malgâche. Cah. O.R.S.T.O.M. (Océanogr.) 3: 1-158

Cummings, W. C. (1960). A preliminary study of the maturation and spawning of the pink shrimp, Penaeus duorarum Burkenroad. M. S. thesis, University of Miami

Cummings, W. C. (1961). Maturation and spawning of the pink shrimp, Penaeus duorarum Burkenroad. Trans. Fish. Soc, 90: $462-468$

Demeusy, N. (1965). Croissance somatique et fonction de reproduction chez la femelle du décapode brachyoure Carcinus maenas Linne. Archs. Zool. exp. gen. 106: 625-663

Eldred, B., Ingle, R. M. Woodburn, K. D., Hutton, R. F., Jones, H. (1961). Biological observations on the commercial shrimp, Penaeus duorarum Burkenroad, in Florida waters. Prof. Pap. Ser. mar. Lab. Fla. 3: 1-139

George, M. J. (1962). On the breeding of penaeids and the recruitment of their postlarvae into the backwaters of Cochin. Indian J. Fish. 9: 110-116

Hall, D. N. F. (1962). Observations on the taxonomy and biology of some Indo-west Pacific Penaeidae (Crustacea, Decapoda). Fishery Publs colon. Off. 17: 1-229

Heydorn, A. E. F. et al. (1978). Ecology of the Agulhas Current region: an assessment of biological responses to environmental parameters in the south-west Indian Ocean. Trans. R. Soc. S. Afr. 43: 151-190

Hudinaga, M. (1942). Reproduction, development and rearing of Penaeus japonicus Bate. Jap. J. Zool. 10: 305-393

Joubert, L. S., Davies, D. H. (1966). The penaeid prawns of the St. Lucia Lake System. Invest. Rep. oceanogr. Res. Inst. 13: $1-40$

King, J. E. (1948). A study of the reproductive organs of the commom marine shrimp Penaeus setiferus (Linndeus). Biol. Bull. mar. biol. Lab. Woods Hole 94: 244-262

Kinne, O. (1977). Cultivation of animals: research cultivation In: Kinne, O. (ed.) Marine ecology, Vol. III. Cultivation, Part 2. Wiley, London pp. 579-1293

Laubier-Bonichon, A., Laubier, L. (1976). Reproduction controlée chez la crevette Penaeus japonicus. FAO technical conference on Aquaculture, Kyoto, Japan, Paper no. E. 38: 1-6

Le Cren, C. D. (1951). The length-weight relationship and seasonal cycle in gonad weights and condition in the perch (Perca fluviatilis). J. Anim. Ecol. 20: 201-219

Le Reste, L., Marcille, J. (1976). Biologie de la crevette Penaeus indicus $\mathrm{H}$. Milne Edward à Madagascar: croissance, recrutement, migrations, reproduction, mortalité. Cah. O.R.S.T.O.M. (Océanogr.) 14: 109-127

Liao, I. C. (1973). Note on the cultured spawner of red-tailed prawn Penaeus penicillatus Alcock. Fishery ser. Chin-Am. jt Comm. rur. Reconstr. 15: 54-65

Lindner, M. J., Anderson, W. W. (1956). Growth, migrations, spawning and size distribution of shrimp, Penaeus setiferus. Fishery Bull. Fish Wildl. Serv. U.S. 56: 555-645

MacGregor, J. S. (1957). Fecundity of the Pacific sardine. Fishery Bull. Fish. Wildl. Serv. U.S. 57: 427-449

Martosubroto, P. (1974). Fecundity of pink shrimp Penaeus duoranum Burkenroad. Bull. mar. Sci. 24: 606-627

Moore, D. W., Sherry, R. W., Montanez, F. (1974). Maturation of Penaeus californiensis in captivity. In: Avault, J. W. (ed.) Proceedings of the Fifth Annual Meeting World Mariculture Society. Louisiana State University, Baton Rouge, pp. 445-450

Panikkar, N. K, Menon, M. K. (1956). Prawn fisheries of India. Proc. Indo-Pacif. Fish. Coun. 6: 328-344

Panouse, J. B. (1943). Influence de l'ablation, de pédoncule oculaire sur la croissance de l'ovaire chez la crevette Leander serratus. C. r. hebd. Séanc. Acad. Sci., Paris 217: $553-555$

Passano, L. M. (1960). Moulting and its control. In: Waterman, T. H. (ed.) The Physiology of Crustacea, Vol. 1. Academic Press, New York, pp. 473-536

Primavera, J. H., Borlongan, E. (1977). Notes on ovarian rematuration of ablated sugpo (prawn) Penaeus monodon Fabricius. Quarterly Research Report SEAFDEC Aquaculture Department 3: 5-8

Rao, P. V. (1967). Maturation and spawning of the penaeid prawns of the southwest coast of India. FAO Fish. Rep. 57: 285-302

Read, G. H. L. (1977). Aspects of lipid metabolism in Penaeus indicus Milne Edwards. M. Sc. thesis, University of NataI, Pietermaritzburg

Read, G. H. L., Caulton, M. S. (in press). Changes in mass and chemical composition during the moult cycle and ovarian maturation in immature and mature Penaeus indicus Milne Edwards. Comp. Biochem. Physiol.

Rice, R. P., Armitage, K. B. (1974). The influence of photoperiod on processes associated with moulting and reproduction in the crayfish Orconectes nais (Faxon). Comp. Biochem. Physiol. 47A: 243-259

Richard, P. (1978). Influence de la temperature sur la croissance et la mue de Palaemon serratus en fonction de leur taille. Aquaculture 14: 13-22

Ryckaert, M., Vial, N., Ceccaldi, H. J. (1974), Effect de l'ablation des pédoncules oculaires en longue et courte photophase sur le developpement des gonads chez Palaemon sematus Pennant. C. r Séanc. soc Biol. 168: 1364-1368

Santiago, A. C. (1977). Successful spawning of cultured Penaeus monodon Fabricius after eyestalk ablation. Aquaculture 11: (3) 185-196 
Snedecor, G. W., Cochran, W. G. (1967). Statistical methods sixth edition, Iowa State University, Ames, Iowa

Solorzano, L. (1969). Determination of ammonia in natural waters by the phenol hypochlorite method. Limnol Oceanogr. 14: 799-801

Subrahmanyam, C. B. (1965). On the reproductive cycle of Penaeus indicus Milne Edwards. J. mar. biol. Ass. India 7: 284-290

Thomas, M. M. (1975). Age and growth, length-weight relationship and relative condition factor of Penaeus semisulcatus De Haan. Indian J. Fish. 22: 133-142
Wear, R. G., Santiago, A. C. (1976). Induction of maturity and spawning in Penaeus monodon Fabricius, 1798, by unilateral eyestalk ablation (Decapoda, Natantia). Crustaceana 31: $218-220$

Weinberg, S. (1976). Submarine daylight and ecology. Mar. Biol. 37: 291-304

Weitzman, M. C. (1964). Ovarian development and moulting in the tropical land crab, Gecarcinus lateralis (Freminville). Am. Zool. 4: 329-330

Wickins, J. F. (1976). The tolerance of warm water prawns to recirculated water. Aquacultire 9: 19-37

This paper was presented by Professor T. M. Fenchel; it was accepted for printing on October 10, 1979. 